K.Ig. SEREBRYAK, PhD in Economics, the Associate Professor at the Department of Enterprise Economy

East Ukrainian National University named after Volodymyr Dahl, Severodonetsk

\title{
THE PROBLEMS OF AGREEMENT PROVISIONS IMPLEMENTATION BETWEEN UKRAINE AND THE EU: INFORMATION SUPPORT
}

Key words: problems, prospects, Association Agreement, public opinion poll.
(C) K.Ig. SEREBRYAK, 2016
In article the results of public opinion poll of the EU countries population are presented, their relationship to the process of expanding the Union is marked, the attitude of Ukrainians to Ukraine's membership of the EU is defined. The problems and prospects of signing the Association Agreement between Ukraine and the European Union were considered. The article is based on the results of research conducted by the Razumkov Centre.

Introduction. The aim of the Association Agreement between Ukraine and the European Union is the integration deepening between Ukraine and EU in the sphere of politics, trade, culture and security. It should be noted that the extension has its social costs - territory, population and overall economic potential of the Union are increasing but at the same time - the economic performance in per capita terms are decreasing. Expanding its socio-economic and political space the EU is sacrificing the current interests of providing maximum life's quality of the Community members for achieving the strategic goals.

Analysis of pasadena exploration thing. The problems and the prospects of signing the Association agreement between Ukraine and the European Union are considered in many scientific and journalistic articles but Razumkov centre and his staff have made a very significant contribution to the study of the relations of Europeans concerning entry of Ukraine into the European Union [1-5]. This requires the generalization and systematization of obtained results.

Purpose of article - is a determination of the population ratio of the European Union to the accession of Ukraine into the European Union, the problems and prospects of agreement implementation in the European Union.

The results of the research. The decision of the fifth enlargement of the EU, as distinct from the previous stages, had rather political than economic motives and remains today major challenge facing the EU currently. The accession of 12 new countries (without Turkey) will increase the territory of the EU by $34 \%$, the population by $28 \%$ while total GDP increased by only $4.8 \%$. Significant reduction of average level of GDP per capita in the EU can cause dissatisfaction of European Union mem- 
ber states by population: the decline in living standards for uncertain compensation in the future is rather controversial formula for pragmatic Europeans [1].

The relation of the EU countries population in view is ambiguous and far from unanimous support of this process. $43 \%$ of the EU countries population agreed that the Union should increasing the new member countries; at the same time, $35 \%$ of respondents do not support the expansion process. Interestingly the majority supporters of EU expansion are living mainly in countries with relatively low levels of economic development. Moreover in the leading countries of the EU that are significantly affect on the definition of the EU strategy, the part of expansion supporters is only slightly more than a third. Quite reluctant EU citizens are relating to the possibility of receiving membership fees to the European Union. Only a fifth of respondents (21\%) believe that the EU should be open to everyone and almost half (44\%) admit such possibility only for individual states.

Taking into account the high level of democracy development in the EU and the fact that the vast majority (71\%) of EU citizens were in favor of postponing the expansion in the event of the discovery of its negative consequences, it can be noted that the enlargement process can become unpredictable from the point of support view for its community of EU member countries. The views of the Ukraine's population are also curious to the borders of which (EU) Ukraine is coming. Our compatriots appreciate positively process of expanding the European Union (EU). The largest part of the population (32.1\%) confident that the process of expanding the EU will improve its relations with Ukraine. Only just one in ten $(9.6 \%)$ held the opposite point of view [1].

It is desirable that the appearance of wealthy neighbor EU - on the Ukrainian border was not a booster of the traditional expectations of aid but also incentive to rebuild their own economy. Now the company has the potential for strengthening European values of the population. It can intensify the improvement of cooperation of Ukraine with the EU, the candidate countries, as well as their interest in the integration of Ukraine into the European community. But this causing our citizens visible skepticism: only $18.4 \%$ of respondents believe that the EU countries related to Ukraine as a potential partner; the majority of the population (62.4\%) believe that the EU members or indifferent to the possible membership of Ukraine in EU (35.4\%) or skeptical, considering that Ukraine has no prospects of joining the EU (27\%).

At the same time our compatriots are aware of the fact of significant economic decline constraining the Ukrainian European integration: the greatest part of the citizens $(39.8 \%)$ believe the real output of our country on the economic level of the EU leading countries only after 20 years. However despite this the majority of them $(66 \%)$ believe that Ukraine should join the EU in the next 5-10 years.

The approach of the EU to the Ukrainian border does not give grounds for overly nice and dramatic scenarios of economic development relations. Obviously it should be soberly recognized that the modern state of the Ukrainian economy and the level of economic cooperation with the EU will not reduce to the rapid accession of Ukraine to the European Union or to its isolation. The consequences of EU expansion for Ukraine will mainly be determined on the one hand by domestic institutional and structural reforms in the European Union in its extended form, by the strategy of the EU's external relations in the Eastern direction, and on the other hand by the ability of Ukraine to effective institutional and structural change within the country. That is the key for Ukrainian European integration should probably be sought not in Brussels but in Kiev.

Membership in the Union last decade has not created significant barriers to the development of trade and economic relations with other countries. Reorientation of the candidate countries on the development of trade and economic relations with the EU basically has already been done. There are no sufficient grounds to assume that the accession of individual countries in the EU must inevitably lead to the collapse of their trade and economic relations with Ukraine [1].

Export and import operations of the candidate countries with the current EU members are already being implemented on the basis of free trade and a common external customs tariff which will join the new members of the Union, on average, lower than existing national customs levels. At the same time in some cases there will be an increasing of the tariff protection level. This is especially concerning the Baltic States. Ukraine with them has signed agreements on free trade which should be null and void after the entry of these countries into 
the EU. The volume of Ukrainian exports to the countries of the region can reach $15-20 \%$.

EU expansion may lead to intensification of competition between Ukrainian producers and enterprises of new EU member states in the single market of the European Union. This will mainly relate the companies of the ferrous metallurgy sector. However this influence may be limited in connection with the adoption of the new EU members the European social standards and norms of environmental protection. Ukraine may even increase their competitive advantage in sectors that are particularly sensitive to competition on price parameters of goods because in the countries - new EU member states will increase the cost of production. This creates the incentives to transfer some of the more simple production facilities on the territory of Ukraine. But such development can be hardly attributed to favorable from the point of long-term strategy view of Ukraine.

The position of the Ukrainian products manufacturers with a high level of added value in the short and medium term will not significantly change - taking into account the small current volumes of such exports to the candidate countries. In the long run they will depend on Ukraine's European technical standards and European quality level [1].

The position of the Ukrainian agrarian producers in the enlarged EU market will depend on two factors: first the level of their compliance with the EU standards; secondly from the changes that will occur in its common agricultural policy. In this context Ukraine should clearly define the priority directions of convergence of Ukrainian and European standards and technical requirements applicable in agriculture.

EU expansion will intensify the promotion of its producers on the markets of third countries therefore it is possible to predict the pressure increasing in terms of the Ukrainian market opening. The expansion of the European Union will bring it to the first place as a market for Ukrainian goods and to the second - as a source of Ukrainian imports. It means that the dynamics of economic processes in the EU will significantly affect on the economic situation in Ukraine, taking into account the high level of its economy openness. The high degree of influence will require the new approaches to the development and implementation of economic policies taking into account the tendencies of world economic development relations and economic conditions particular in Europe.

Meanwhile, the CIS countries (primarily Russia) will hold the championship in the Ukrainian import. Consequently, a foreign trade of Ukraine will be characterized by increasing tendency of the presence on the EU market while in short imports and even in medium term will continue the dominance of the CIS countries [1].

In general the roots of the most problems for Ukrainian exporters which will arise due to the EU expansion, the gap of Ukraine from candidate countries in the field of market-oriented socioeconomic transformation and rate of economic and technological modernization, affecting on competitiveness in an open market environment.

Do not being a WTO member Ukraine can not effectively resist in the future to use the additional anti-dumping and countervailing measures from the side of the new EU members. It is another argument in favor of the necessity of Ukraine's accession to the world trade organization that will allow to use the internationally established mechanisms to protect interests in these matters. In connection with the EU expansion for Ukraine becomes relevant to the question of trade regime improvement with the EU as a whole. In particular about assignment to Ukraine the status of market economy state in full. In the long term the solutions to many problems may be the conclusion of a free trade agreement between Ukraine and the EU which provided the current Agreement on partnership and cooperation.

The movement of the EU to the East will be accompanied by the introduction of the visa regime by the neighboring candidate countries, strengthening border control, strengthening the fight against illegal migration which affects the interests of millions our compatriots.

The issue of labor migration regulation and social protection of Ukraine citizens becomes relevant in this context. By the way after leading of the European regulation to the candidate countries of this sector will lead to limitation of the employment opportunities of the Ukraine citizens [1].

On the other hand it is no secret that most of labour flow resources of Ukraine to the West is illegal labour migration provoking problematic in relations of Ukraine with the EU and member candidates.

At the same time only just restrictive measures by the EU and the candidate countries will not

ISSN 1681-6277. Економіка та право. № 2 (44), 2016 
solve the problem of the illegal employment eradication of Ukrainian citizens in their territories. It is clear that in the near future Ukraine will not be able to dramatically reduce unemployment with its own forces and significantly improve living standards. Therefore the proposal of undocumented workers from Ukraine will stimulate the demand side of the informal sector in the EU.

It is also clear to overcome the illegal labour migration there is a lack of Ukraine's efforts. It is necessary together with the EU and the candidate countries to comprehensively address this problem: from helping to create working place in Ukraine - up to the legalization of labour migration flows by increasing the respective quotas. In the medium term the establishment of agreements between Ukraine and EU on labour migration and social protection of Ukrainian workers abroad is necessary.

Strengthening the fight against illegal migration in the enlarged Euroclub, establishing on its borders the anti-immigration barriers in the form of strict border and visa regimes can largely shift the burden of this transnational problem in our country. Ukraine may turn into the state for illegals storage that will destabilize the internal situation. Consequently there is a zone of instability directly beyond the borders of the European Union [1].

The struggle of the EU with illegals needs not only the establishment of barriers on the Western border of Ukraine but also putting in order all the borders in Eastern Europe and especially Eastern and Northern borders of Ukraine, through which the main transit flow of illegals comes to Ukraine.

The introduction of the visa regime may affect on the freedom of Ukrainian citizens movement and on their welfare.

Visa regime of border crossing procedures, border control procedures and measures to eliminate illegal migration is a common international practice. But in the Ukraine's situation the introduction of visas is combined with the internal problems: the low level of citizens life forcing them in particular to dump at the labour market, participation in criminal activities, etc.; a lack of legal culture (behavior of our citizens abroad is a separate issue and not a very pleasant conversation). In particular it explains the desire of EU member states and candidate countries to dissociate themselves from Ukraine due to the barrier visas and strict border control procedures. It is necessary to minimize the negative impact of these EU measures on the Ukrainian citizens - primarily to bring in correspondence with EU standards an internal socio-economic situation in Ukraine.

On the other hand it is necessary to implement the specific adaptation measures before introducing a visa regime with Ukraine: to expand the network of consular offices, to simplify the procedure for registration of documents, to establish the optimal cost of visas.

Upon the completion of current phase of EU expansion the Ukraine's Western borders will become the Eastern frontier of the European Union. It is a qualitatively new political situation which will largely determine the nature of the contacts with our European partner and also the prospects for further development of Ukraine [1].

In the interest of the EU to ensure word and stability on its borders, to have as its neighbors, a stable, democratic and economically developed state with a predictable and friendly foreign policy. Therefore we should expect increasing of EU political pressure on Ukraine primarily in the direction of strengthening democratic institutions, human rights, media freedom, organized crime and corruption in the government. Obviously this pressure will most likely feel in the coming months, given the upcoming parliamentary elections in Ukraine. From their transparency, democracy, in conformity with European standards will depend the future EU relations with Ukraine and prospects of European countries integration in general.

The movement of the EU to the Ukrainian borders on the background of a Common European Policy Security and Defense development will allow our state to take a more active part in strengthening security on the continent. Today in the sphere of security Ukraine can make a real contribution to stability in the zone of interests of the EU - along the lines of peacekeeping, disaster relief situations, strategic transport, etc.

The EU accession of the states with which Ukraine has traditionally good relations and receiving by them the quotas in the governing bodies of the Union can contribute the promotion of Ukrainian interests in the EU and will allow use tested mechanisms for regional cooperation to deepen contacts with the European Union.

We should emphasize one important fact. EU expansion is accompanied by deepening EU cooperation with Russia. Consequently Ukraine's movement to Europe, among other things, will define by the level and nature of its relations with Russia. 
In particular it is necessary to deepen economic cooperation with Russia for strengthen the national economy as a basis for the realization of their political aims in Europe [1].

Summary. In general the approach of the EU to the Ukrainian borders is objectively strengthen the impact of the European Community on Ukraine. In political terms this process can be considered as positive because it contributes the implementation of the European standards in Ukraine. At the same time the transformation of the EU can create many problems for Ukraine. It is obvious that the nature and level of cooperation between Ukraine and the enlarged EU, the prospect of Ukrainian European integration will depend primarily on internal transformations in Ukraine, the conditions creation for stable democratic development, the rise of the domestic economy.

\section{REFERENCES}

1. Official website of the Razumkov Centre (2015), available at: http://razumkov.org.ua/ukr/index.php (Accessed $28 \mathrm{Apr}$ 2016).

2. Markevich K. (2014), How the Ukrainian business is obtaining a free trade area with the EU, available at: http:// razumkov.org.ua/ eng/article.php?news_id=1303 (Accessed 20 Marz 2016)

3. Pashkov M. (2015), Ukraine and EU enlargement: problems, consequences and prospects, available at: http:// www.uceps.org/ eng/article.php?news_id $=165$

4. Pashkov M. (2015), President Poroshenko brought the relations with the EU to a new level, available at: http:// www.uceps.org/ukr/expert.php?news_id $=5621$ (Accessed 28 Apr 2016)

5. Pashkov M. (2014), Ratification of the Association Agreement minimizes the threats to the relations of Ukraine with the EU / available at: http://www.uceps.org/ukr/expert. php?news id=4923 (Accessed 25 Apr 2016).

К.И. Серебряк

Надійшла 10.05.2016

Восточноукраинский национальный университет

имени Владимира Даля, Северодонецк

\section{ПРОБЛЕМЫ РЕАЛИЗАЦИИ ПОЛОЖЕНИЙ СОГЛАШЕНИЯ МЕЖДУ УКРАИНОЙ И ЕС ИНФОРМАЦИОННАЯ ПОДДЕРЖКА}

Представлены результаты социологического опроса населения стран ЕС, их отношения к процессу расширения Евросоюза. Оценено отношение украинцев к вступлению Украины в ЕС. Рассмотрены проблемы и перспективы подписания соглашения об ассоциации между Украиной и Европейским Союзом. Статья основана на результатах исследования, проведенного Украинским центром экономических и политических исследований имени Александра Разумкова.

Ключевые слова: проблемы, перспективы, Соглашение об ассоциации, социологический опрос.

\section{K.I. Серебряк}

Східноукраїнський національний університет імені Володимира Даля, Сєвєродонецьк

ПРОБЛЕМИ РЕАЛІЗАЦІЇ ПОЛОЖЕНЬ

УГОДИ МІЖ УКРАЇНОЮ ТА ЕС: ІНФОРМАЦІЙНА ПІДТРИМКА

Представлені результати соціологічного опитування населення країн $\mathrm{CC}$, їх відношення до процесу розширення Евросоюзу. Визначено ставлення українців до вступу України в СС. Розглянуто проблеми та перспективи підписання угоди про асоціацію між Україною та Європейським Союзом. Стаття базується на результатах дослідження, проведеного Українським центром економічних і політичних досліджень імені Олександра Разумкова.

Ключові слова: проблеми, перспективи, Угода про асоціацію, соціологічне опитування. 